\title{
Do self-esteem and gender help explain depressive and/or anxiety symptoms in adolescents?
}

\author{
Brenda Fernanda Pereira da Silva ${ }^{1}$, Laís Santos Vitti ${ }^{2}$, Sônia Regina Fiorim \\ Enumo $^{3}$ e André Faro ${ }^{4}$ \\ Universidade Federal de Sergipe-Brasil y Pontificia Universidade Católica de \\ Campinas-Brasil
}

Depression and anxiety are common in adolescents, and poor mental health in this group leads to harm in adulthood. This study investigates to what extent gender, age, body image dissatisfaction, and self-esteem were related to depressive and anxiety symptoms in adolescents. The sample consisted of 1,209 high school students of both sexes, aged 13-19 years $(M=15.8 ; S D=1.23)$. The instruments were: sociodemographic questionnaire, Rosenberg Self-Esteem Scale (RSES), Stunkard Figure Scale and the Hospital Anxiety and Depression Scale (HADS). Multinomial logistic regression indicated that being female and having low or moderate self-esteem satisfactorily explained the anxiety symptoms. Reduced self-esteem was the best explanation for depressive symptoms, and finally, reduced rates of self-esteem satisfactorily explained symptoms for both disorders.

Keywords: anxiety, depression, self-esteem, body image, adolescent.

\section{¿La autoestima y el género explican la depresión/ansiedad en los adolescentes?}

La depresión y la ansiedad son comunes en los adolescentes, y los problemas de salud mental en este grupo provocan daños en la vida adulta. Este estudio investigó cómo el sexo, la edad, la insatisfacción con la imagen corporal y la autoestima se relacionan con los síntomas depresivos y ansiosos en los adolescentes. Participaron 1.209 adolescentes de ambos sexos, entre 13 y 19 años $(M=15,8 ; \mathrm{DE}=1,23)$. Los instrumentos fueron: cuestionario sociodemográfico, RSES, Escala de figuras de Stunkard y HADS. La regresión logística multinomial

1 Mestre em Psicologia pela Universidade Federal de Sergipe (UFS). Endereço postal: Departamento de Psicologia, UFS. Avenida Marechal Rondon, s/n. Conjunto Rosa Elze, São Cristóvão Sergipe, Brasil. CEP 49000-000. Contato: brendafernandapsi@gmail.com

2 Doutoranda em Psicologia pela Pontifícia Universidade Católica de Campinas. Bolsista pela Coordenação de Aperfeiçoamento de Pessoal de Nível Superior (CAPES). Endereço postal: Avenida John Boyd Dunlop s/n, Jardim Ipaussurama, Campinas, São Paulo, Brasil. CEP 13034-685. Contato: laiss.santos9597@gmail.com.

3 Docente do Programa de Pós-Graduação Stricto Sensu em Psicologia da Pontifícia Universidade Católica de Campinas. Endereço postal: Avenida John Boyd Dunlop s/n, Jardim Ipaussurama, Campinas, São Paulo, Brasil. CEP 13034-685. Contato: sonia.enumo@gmail. com

4 Docente da graduação e do Programa de Pós-Graduação em Psicologia. São Cristóvão, Sergipe, Brasil. Endereço postal: Departamento de Psicologia, UFS. Avenida Marechal Rondon, s/n. Conjunto Rosa Elze, São Cristóvão - SE, CEP 49000-000. Contato: andre.faro.ufs@ gmail.com 
indicó que ser una niña y tener una autoestima baja o moderada explicaban los síntomas de ansiedad satisfactoriamente. La autoestima reducida fue la mejor explicación para los síntomas depresivos y de ambos desordenes.

Palabras clave: ansiedad, depresión, autoestima, imagen corporal, adolescente.

Autoestima e sexo ajudam a explicar sintomas depressivos e/ou ansiosos em adolescentes? Depressão e ansiedade são comuns em adolescentes, e problemas de saúde mental nesse grupo levam a danos na vida adulta. Este estudo investigou como sexo, idade, insatisfação com a imagem corporal e autoestima relacionam-se a sintomas depressivos e ansiosos em adolescentes. Participaram 1.209 adolescentes de ambos os sexos, com idades entre 13 e 19 anos $(M=15,8 ; D P=1,23)$. Os instrumentos utilizados foram: questionário sociodemográfico, Escala de AutoEstima de Rosenberg (RSES), Escala de Silhuetas de Stunkard e Escala Hospitalar de Ansiedade e Depressão (HADS). A regressão logística multinomial indicou que ser menina e ter baixa ou moderada autoestima explicaram satisfatoriamente sintomas ansiosos. Autoestima reduzida foi a melhor explicação para sintomas depressivos e sintomas de ambos os distúrbios.

Palavras-chave: ansiedade, depressão, autoestima, imagem corporal, adolescente.

\section{L'estime de soi et le sexe expliquent-ils la dépression/l'anxiété chez les adolescents?}

La dépression et l'anxiété sont courantes chez adolescents, et les problèmes de santé mentale dans ce groupe entraînent des dommages à l'adulté. Cette étude a examiné comment le sexe, l'âge, l'insatisfaction à l'égard de l'image corporelle et l'estime de soi sont liés aux symptômes dépressifs et anxieux chez adolescents. Ont participé 1209 adolescents des deux sexes, âgés de 13 à $19(M=15,8 ; E T=1,23)$. Les instruments étaient questionnaire sociodémographique, RSES, l'échelle de la figure Stunkard et HADS. La régression logistique a indiqué qu'être une fille et avoir une estime de soi faible/modérée expliquaient les symptômes d'anxiété de manière satisfaisante. Une diminution de l'estime de soi était la meilleure explication des symptômes dépressifs et symptômes des deux troubles.

Mots-clés: anxiété, dépression, estime de soi, image corporelle, adolescent. 
Common Mental Disorders (CMD) are responsible for much of the disability and burden of disease worldwide (World Health Organization [WHO], 2017). In South America, CMD have been a major cause of increased disability and mortality rates (Pan American Health Organization [PAHO], 2018). The main CMD are Depressive and Anxiety Disorders, which affect, respectively, 322 million and 264 million people worldwide, and there may even be comorbidities between them (WHO, 2017).

Depressive Disorders can be highly limiting and have been recognized as the leading cause of disability in Latin America, such that Brazil ranks second in Years Lived with Disability (YLD) ranking in the role of depression (PAHO, 2018). According to the DSM-5, the most common feature of Depressive Disorders is the presence of sad, empty or irritable mood, accompanied by cognitive and somatic changes that significantly impact the daily functioning of affected individuals (American Psychiatric Association [APA], 2014).

Depressive Disorders have mostly affected young people, such that around 10 of the 14.5 million years experienced with disability due to depression in the Americas are in the 15-50 age group (PAHO, 2018). In Brazil, the prevalence among individuals aged 10-24 years is estimated at $8 \%$ of the population (Institute for Health Metrics and Evaluation [IHME], 2017). Despite their high prevalence, depressive disorders are usually underdiagnosed in young people (Resende et al., 2013; WHO, 2018). In adolescents, the most common symptoms are depressive mood, sadness, irritability, loss of interest or pleasure in daily activities, weight changes, insomnia or hypersomnia, and psychoactive substance abuse (APA, 2014; Gonçalves \& Sampaio, 2016).

Anxiety Disorders have played the role of the second most disabling mental disorder in most American countries, while Brazil occupies first place in the ranking of years lived with anxiety disability 
(PAHO, 2018). As a basic characteristic, anxiety disorders are those that present excessive fear and anxiety directed to either specific activities or not (APA, 2014). Fear and anxiety are considered common and adaptive physiological responses, but once these responses are disproportionate to the aversive stimulus, it is understood that anxiety has become a disease. Globally, anxiety has affected approximately 12\% of individuals between 10-24 years. In Brazil, 18\% of adolescents and young people in this age group have anxiety disorders (IHME, 2017). Regarding symptoms, it is common for adolescents to worry excessively about school activities and their performance, because the school environment is a place where the signs of suffering due to anxious behavior become more evident (APA, 2014).

Depressive and anxiety disorders present differentiated involvement with regard to gender. Females have 1.5 to 3 times higher rates of depressive symptoms than males and it is common for the disorder to start in adolescence (APA, 2014). Anxiety disorders have already been present in women twice as much as in men (APA, 2014). Therefore, it can be seen that the social distribution of depression and anxiety tends to differ according to the gender variable.

Depressive and anxiety disorders in adolescence cause enormous harm in daily functioning, associated with lower levels of general health, higher frequency of suicidal ideation and lower school performance, for instance. Furthermore, comorbidity between depression and anxiety disorders are very harmful, intensifying the limitations already caused by the disorders (APA, 2014). Consequently, highlighting the importance of identifying the characteristics that increase or reduce the probability of the occurrence of depressive and anxiety disorders in adolescence, i.e., their risk and protection factors (Das et al., 2016; Faro \& Kluge, 2018; Lopes et al., 2016).

Recent studies have pointed to the association between self-esteem and body image and the occurrence of depressive and anxiety symptoms in adolescents (Tuijl et al., 2014; Rentz-Fernandes, Silveira-Viana, \& Andrade, 2017), which makes the investigation of these variables relevant. Thus, by identifying the harmful variables to the mental health 
Do self-esteem and gender help explain depressive and/or anxiety symptoms / Silva et al.

of adolescents, it is possible to obtain information regarding prevention and health promotion, in addition to performing interventions aimed a better adjustment (Faro \& Kluge, 2018).

\section{Self-esteem, body image and the influence on mental bealth of adolescents}

Self-esteem has been a construct largely related to adolescent mental health (Hutz \& Zanon, 2011; Sena \& Maia, 2017) and, especially when diminished, is associated with the presence of depressive and anxiety disorders (Tuijl et al., 2014). Self-esteem consists of a set of thoughts and feelings regarding self-worth, reflected through positive or negative attitudes toward oneself (Hutz \& Zanon, 2011). This construct has been associated with general health, both as a protective factor, mitigating damage resulting from illness, and as an indicator of the presence of several psychopathologies (Hutz \& Zanon, 2011).

Adolescence is a transitional period due to the biological, cognitive and relational changes that it causes (Gonçalves \& Martínez, 2014; Gonçalves \& Sampaio, 2016; Resende et al., 2013; Silva et al., 2018). This is a period of greater susceptibility to the development of mental disorders. For example, lower levels of self-esteem during early adolescence may be associated with vulnerability to the development of depressive and anxiety symptoms (Tuijl et al., 2014).

Regarding social distribution, boys and girls differ in their perception of self-esteem; girls tend to show lower rates (Rentz-Fernandes et al., 2017; Silva et al., 2018). It is believed that this fact is due to the higher pressure suffered to conform with aesthetic standards imposed by society, which can generate psychological suffering, justifying the need to investigate the influence of self-esteem in the occurrence of CMD in adolescents. Moreover, there is an inversely proportional correlation between age and self-esteem, in that the higher the age, the lower the self-esteem levels (Hutz \& Zanon, 2011).

Self-esteem has been associated with body image in adolescence since the constructs exhibit theoretical similarity. Body image is com- 
prised of perceptions, thoughts, feelings, and attitudes towards one's own body, whereas dissatisfaction with body image consists of negative thoughts and feelings about one's own body (Grogan, 2008). By triggering negative emotions and attitudes about appearance, dissatisfaction impacts on psychological well-being, and quality of life (Del Ciampo \& Del Ciampo, 2010).

Data on the presence of body dissatisfaction tend to differ according to gender. Girls have shown greater body dissatisfaction than boys, and most girls have wanted to lose weight, while boys aim to gain weight (Gonçalves \& Martínez, 2014; Miranda et al., 2014; Rentz-Fernandes et al., 2017). Age can also influence body dissatisfaction among adolescents. Those in early adolescence (10-13 years) and intermediate (14-16 years) are between $45 \%$ to $56 \%$ less likely to be dissatisfied with their bodies compared to those in late adolescence (17-21 years) (Miranda et al., 2014). Self-esteem and body image dissatisfaction can be variables that help to understand the social distribution of common mental disorders in adolescence, mainly because they are considered a risk factor for developmental impairment and repercussion in later life cycles (Das et al., 2016).

This study aimed to investigate to what extent gender, age, body image dissatisfaction, and self-esteem are related to depressive and anxiety symptoms in adolescents. Specifically, we sought to: (a) assess self-esteem levels among adolescents by analyzing differences by gender and age; (b) identify the level of body dissatisfaction in adolescents; (c) investigate how much these variables explain the presence of depressive and anxiety symptoms in adolescents.

\section{Method}

\section{Participants}

This cross-sectional study was carried out with 1,209 high school students of both sexes, with $48.1 \%(n=582)$ from public schools and $51.9 \%(n=627)$ from private schools, from three rural cities and the 
capital of the State of Sergipe, Brazil. Ages ranged from 13-19 years, with an average age of 15.8 years $(S D=1.23$; Median $=16.0)$. This sample was taken from a databank of 1.483 participants, whose data were collected over three years (2015-2017), excluding 274 participants due to missing cases.

\section{Instruments}

A sociodemographic questionnaire consisting of questions related to gender (male or female), age (in years), grade (1st, $2 \mathrm{nd}$, or 3 rd year of high school), type of school (public or private) and city of residence.

The Rosenberg Self-Esteem Scale (RSES - Rosenberg, 1965) was translated and adapted to Brazil by Avanci, Assis, Santos, and Oliveira (2007). The RSES consists of 10 items (five positive and five negative) and contains a four-point response scale, with the following options: "strongly agree", "agree", "disagree" and "strongly disagree". The higher the score, the higher the level of self-esteem.

The Hospital Anxiety and Depression Scale (HADS) was translated and adapted to Brazil by Botega et al. (1995). It is composed of 14 items and divided into two subscales: the first has seven questions and refers to the presence of anxiety symptoms (odd items), and the second, also with seven questions, points to the presence of depressive symptoms (even items). Responses range from zero to three points (absent to very frequent), with a maximum score of 21 points per subscale, with a cut-off point of $\geq 9$ for anxiety and depression (Zigmond \& Snaith, 1983). Although originally designed for the clinical and hospitalized population, HADS is understood to be a useful tool for screening of depressive and anxiety symptoms in hospitalized adolescents and non-clinical samples as it is a short, easy-to-administer, reliable, and satisfactory sensitivity scale (Chan, Koh, \& Lee, 2014).

To measure body image dissatisfaction, the Stunkard Figure Rating Scale was used (Stunkard, Sorensen, \& Schulsinger, 1983; adapted to Brazil by Scagliusi et al., 2006). The version applied has eight silhouettes that ranged from extreme thinness to extreme obesity, numbered 
from one to eight. Silhouettes are illustrated in female and male bodies. Initially, the respondent indicates which figure is similar to their actual/ current body. After that, he/she is required to point out his/her ideal body; that is, the one they would like to have. The dissatisfaction index is obtained by subtracting the actual image from the idealized body image. Those who had a non-zero result were considered dissatisfied, and the higher the value obtained, the greater the dissatisfaction (disregarding the negative sign resulting from the subtraction).

\section{Procedures}

Authorizations from school principals and parents were obtained for data collection and the questionnaires were answered in the classrooms. Those who agreed to participate received instructions and then granted their participation in the study through the terms of consent. The application of the instruments lasted an average of 15 minutes and they were all self-administered.

\section{Ethical aspects}

The data from this study is part of broader research aimed at detecting depressive and anxiety symptomatology in the State of Sergipe, Brazil. This study was submitted to the Human Research Ethics Committee, obtaining approval (register: information omitted for evaluation).

\section{Data analysis}

Data were analyzed using SPSS software (version 24). Descriptive and exploratory analyses were performed such as frequencies, averages, medians, standard deviations, and percentages. Regarding the inferential analyses, initially, bivariate relationship analyses were performed between the dependent variable (DV - the presence of depressive or anxiety symptomatology) and the independent variables (gender, age, body image dissatisfaction, and self-esteem). The Chi-squared test $[\chi 2$ 
(degrees of freedom)] was used to investigate which independent variables would be used in the multivariate statistical analysis.

After bivariate analysis, the analysis of a Multinomial Logistic Regression model was conducted. This analysis is performed when the dependent variable has more than two categories or groups. The dependent variable (diagnosis of anxiety or depression with HADS), after classification of scores, resulted in the following groups: (0) none of the disorders, (1) presence of significant symptoms for anxiety disorder, (2) presence of symptoms significant for depressive disorder, and (3) both disorders. Explanatory variables were gender, self-esteem, dissatisfaction with body image and the series, considering that the latter was evaluated as a non-metric equivalent for the age variable.

The model's fit was assessed by the analysis of the Odds Ratio (OR), Nagelkerke index (explained variance), the predictive ability of the model (desired values from $60 \%$ of cases correctly predicted), the Goodness of Fit (desired value being non-significant), and the initial and final -2 log Likelihood (expected a difference greater than 40 points for a good fit of the model) (Garson, 2012). For detecting eventual multicollinearity (Field, 2009), bivariate analyses were performed after reaching the final model.

\section{Results}

\section{Sample profile}

The sample consisted of $59.6 \%$ girls $(n=720)$. In terms of the grade level, $42.4 \%(n=513)$ were in the first year of high school, $34.4 \%(n=416)$ were in the second year and $23.2 \%(n=280)$ in the third year. It was observed that $8.6 \%(n=104)$ of adolescents met the criteria exclusively for anxiety symptomatology in HADS and $2.6 \%$ $(n=31)$ had only significant depressive symptoms; however, $70.1 \%$ ( $n=848)$ of respondents indicated significant symptomatology for both disorders (anxiety and depression). The remaining $(18.7 \% ; n=$ 226) did not show significant symptoms for any of the disorders. 
The median of self-esteem was 27 points $(\operatorname{Min}=6 ; \operatorname{Max}=36)$. In this study, due to the insertion in the logistic model, the variable was transformed into non-metric, so that three groups were created (low self-esteem, from 0 to 24 points; moderate, from 25 to 28 points; high, over 29 points) based on the tertiles distribution. It was observed that $33.1 \%$ of the adolescents $(n=400)$ comprised the low self-esteem group, $28.4 \%(n=343)$ belonged to the moderate self-esteem group and $38.5 \%$ of the students $(n=466)$ high self-esteem rates.

The median of body image dissatisfaction was 1 point $(\operatorname{Min}=0$; Max = 5), which indicated low dissatisfaction. In this study, it was only considered significant dissatisfaction above 2 points. Given this finding, we analyzed the distribution of cases, admitting cut-off point 2 for the creation of a non-metric variable to be included in the regression model (with dissatisfaction and without dissatisfaction). Body dissatisfaction was observed in $23.7 \%$ of adolescents $(n=287)$, i.e., this was the number of adolescents who exhibited discrepancy between the actual silhouette and the ideal silhouette at or above 2 points.

\section{Bivariate relationships between sex, grade, self-esteem, body image dissatisfaction and depression and/or anxiety}

Bivariate analyses were performed between the dependent variable (anxiety or depressive symptomatology, both disorders or none) and all independent variables tested to verify the relevance or not of inclusion in the logistic regression model. The variables gender $(\chi 2(3)=17.584$; $p=.001)$, grade $(\chi 2(6)=28.429 ; p<.001)$, and self-esteem $(\chi 2(6)=$ $65.027 ; p<.001)$ were statistically significant. The association with the body image dissatisfaction variable was not statistically significant $(p>$ $.05)$ and was not included in the logistic regression.

It was observed that $69.1 \%(n=338)$ of the males presented both disorders, $5.3 \%(n=26)$ reported only anxiety symptoms and $3.1 \%$ $(n=15)$ only depressive symptoms. In the female group, $70.8 \%(n=$ $510)$ had anxiety and depressive symptoms, $10.8 \%(n=78)$ indicated anxiety symptoms, and $2.2 \%(n=16)$ only depressive symptoms. As 
for grade level, $77.6 \%(n=398)$ of first year students, $62.7 \%(n=261)$ of second year and $67.5 \%(n=189)$ had symptoms for both disorders. Finally, $77.8 \%(n=311)$ of adolescents with low self-esteem and $68.8 \%(n=236)$ of those with moderate self-esteem exhibited anxiety and depressive symptoms.

\section{Multivariate analysis of gender, grade, and self-esteem for symptoms of anxiety and/or depression}

Explanatory variables included gender, grade, and self-esteem. The final regression model obtained an acceptable solution $(p<.001)$, with just over $10.0 \%$ of explained variance $($ Nagelkerke $=.105)$, with a total correct predictive capacity of $70 \%$. The values obtained were satisfactory for the Goodness of Fit $(p=.656)$ and for the $-2 \log$ Likelihood rates (initial $=310.608-$ final $=201.431 ; \Delta-211=109.177)$. No multicollinearity problems were detected, as well as the other assumptions were met.

Multinomial Logistic Regression results are read out as follows: there is a reference group (in this case, no disruption present) and this group is compared with the presented result. In other words, it is understood that there is a greater chance for a phenomenon to occur in a particular group compared to the reference group. Having clarified this, the results of the group with "the presence of anxiety symptomatology" were compared to those who indicated no symptomatology for "no disorder".

In the results, females showed approximately two times $(O R=2.1$; $p=.004)$ the chances of belonging to the group with anxiety symptoms compared to having no disorder. The "low self-esteem" category increased the odds of exhibiting anxiety symptoms by almost eight times more $(O R=7.6 ; p<.001)$, while having "moderate self-esteem" increased by three times $(O R=3.0 ; p<.001)$ this chance. Although statistically borderline $(p<.10)$, being in the third year increased by almost two times $(O R=1.7 ; p=.094)$ the chances of belonging to the group with anxiety symptoms compared to having no disorder. It is 
noteworthy that the ORs related to gender and grade were below 1, needing to convert their values by the formula " $1 / O R$ ", aiming to standardize the interpretation of the ORs (> 1) as exposure factor (Table 1).

Regarding the comparison between "depressive symptomatology" and "no disorder", it was found that presenting "low self-esteem" increased the chances of belonging to the group with depressive symptoms by three and a half times $(O R=3.5 ; p=.007)$ compared to not having any disorders. The other variables did not show statistical significance (Table 1).

When comparing "positive symptoms for both disorders" and "no disorders", it was observed that being in the "low self-esteem" group increased the odds of having both disorders by four times $(O R=4.0 ; p$ $<.001)$ compared to having no disorder, whereas exhibiting "moderate self-esteem" increased those odds by one and a half times $(O R=1.5 ; p=$ .017). The grade level once again appeared borderline, which indicates that being in the first year of high school increased by almost one and a half times $(O R=1.3 ; p=.097)$ the chances of having both disorders, compared to not having any (Table 1). The illustration of the frequency differences by group concerning the DV is shown in Figure 1. 
Do self-esteem and gender help explain depressive and/or anxiety symptoms / Silva et al.

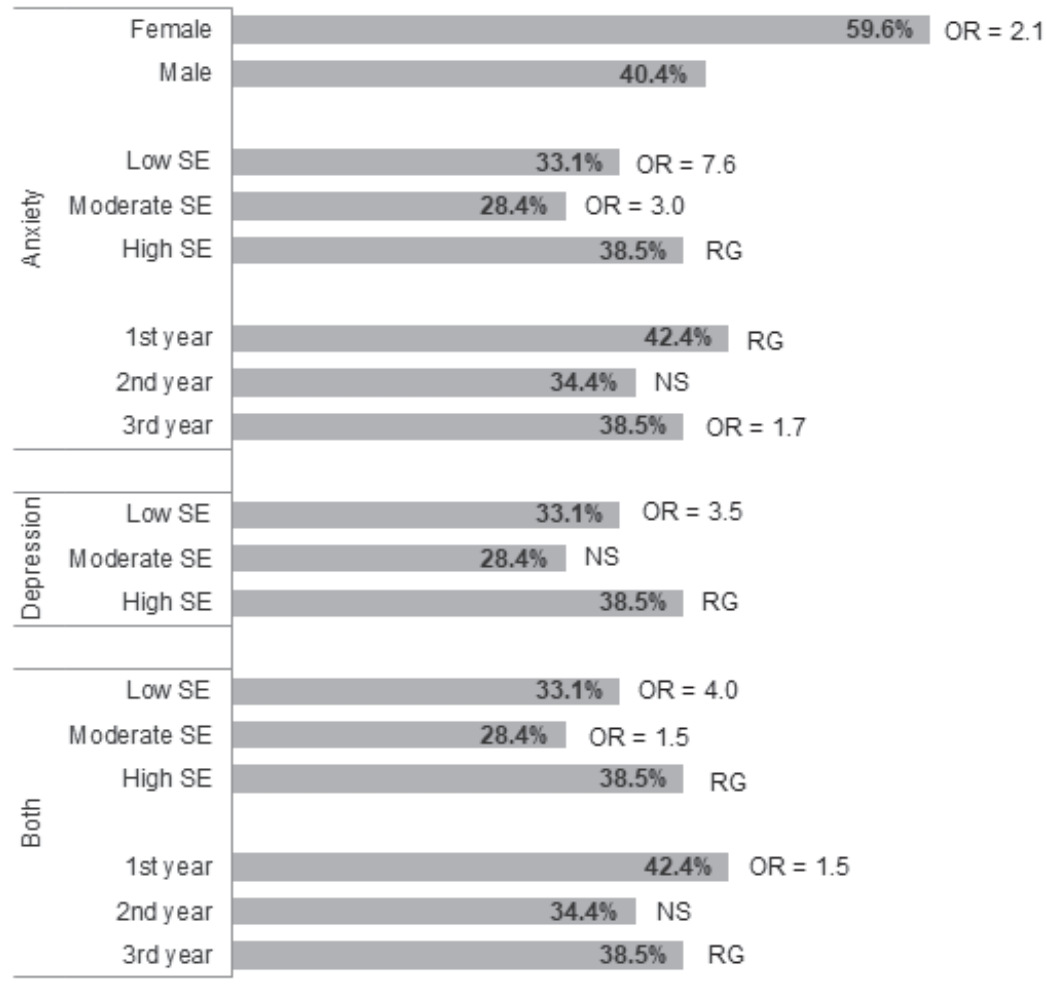

Figure 1. Percentage frequency of independent variables (Male or Female gender, self-esteem [SE] and grade [1st, 2nd or 3rd year]), respective ORs and reference groups (RG), concerning the dependent variable categories (presence of anxiety symptoms, depressive symptoms or both disorders). NS = not significant. 


\section{Table 1}

Multinomial Logistic Regression Results for Anxiety, Depression, and Both Disorders in a Sample of Adolescents in Sergipe

\begin{tabular}{|c|c|c|c|c|c|c|c|c|}
\hline \multirow{2}{*}{\multicolumn{2}{|c|}{ Variables }} & \multirow{2}{*}{$\begin{array}{c}\mathrm{F} \% \\
(\mathrm{n}=1209)\end{array}$} & \multicolumn{2}{|c|}{ Anxiety symptoms } & \multicolumn{2}{|c|}{$\begin{array}{l}\text { Depressive } \\
\text { symptoms }\end{array}$} & \multicolumn{2}{|c|}{ Both disorders } \\
\hline & & & $\begin{array}{c}\text { OR } \\
(\mathrm{CI} 95 \%)\end{array}$ & $\begin{array}{c}p- \\
\text { value }\end{array}$ & $\begin{array}{c}\text { OR } \\
(\mathrm{CI} 95 \%)\end{array}$ & $\begin{array}{c}p- \\
\text { value }\end{array}$ & $\begin{array}{c}\text { OR } \\
(\mathrm{CI} 95 \%)\end{array}$ & $p$-value \\
\hline \multirow[t]{2}{*}{ Gender } & Female & $\begin{array}{l}59.6 \\
(720)\end{array}$ & $\begin{array}{c}2.1 \\
(1.2-3.7)\end{array}$ & $.004^{\mathrm{a}}$ & $\begin{array}{c}.8 \\
(.4-1.9)\end{array}$ & .748 & $\begin{array}{c}1.2 \\
(.9-1.6)\end{array}$ & .210 \\
\hline & Male & $\begin{array}{l}40.4 \\
(489)\end{array}$ & 1 & - & 1 & - & 1 & - \\
\hline \multirow[t]{3}{*}{$\begin{array}{l}\text { Self- } \\
\text { esteem }\end{array}$} & Low & $\begin{array}{l}33.1 \\
(400)\end{array}$ & $\begin{array}{c}7.6 \\
(3.9-14.5)\end{array}$ & $<.001^{\mathrm{a}}$ & $\begin{array}{c}3.5 \\
(1.4-8.7)\end{array}$ & $.007^{\mathrm{a}}$ & $\begin{array}{c}4.0 \\
(2.6-6.1)\end{array}$ & $<.001^{\mathrm{a}}$ \\
\hline & $\begin{array}{l}\text { Mode- } \\
\text { rate }\end{array}$ & $\begin{array}{l}28.4 \\
(343)\end{array}$ & $\begin{array}{c}3.0 \\
(1.6-5.7)\end{array}$ & $<.001^{\mathrm{a}}$ & $\begin{array}{c}1.1 \\
(.4-2.9)\end{array}$ & .836 & $\begin{array}{c}1.5 \\
(1.0-2.1)\end{array}$ & $.017^{\mathrm{a}}$ \\
\hline & High & $\begin{array}{l}38.5 \\
(466)\end{array}$ & 1 & - & 1 & - & 1 & - \\
\hline \multirow[t]{3}{*}{ Grade } & $\begin{array}{l}1 \text { st } \\
\text { year }\end{array}$ & $\begin{array}{l}42.4 \\
(513)\end{array}$ & $\begin{array}{c}.5^{c} \\
(.3-1.0)\end{array}$ & $.094^{\mathrm{b}}$ & $\begin{array}{c}1.1 \\
(.4-3.0)\end{array}$ & .799 & $\begin{array}{c}1.3 \\
(.9-2.0)\end{array}$ & $.097^{\mathrm{b}}$ \\
\hline & $\begin{array}{l}2 \text { nd } \\
\text { year }\end{array}$ & $\begin{array}{l}34.4 \\
(416)\end{array}$ & $\begin{array}{c}.8 \\
(.4-1.5)\end{array}$ & .961 & $\begin{array}{c}.9 \\
(.3-2,5)\end{array}$ & .883 & $\begin{array}{c}.7 \\
(.5-1.1)\end{array}$ & .147 \\
\hline & $\begin{array}{l}3 \mathrm{rd} \\
\text { year }\end{array}$ & $\begin{array}{l}23.2 \\
(280)\end{array}$ & 1 & - & 1 & - & 1 & - \\
\hline
\end{tabular}

Notes. $1 . F \%=$ percentage frequency; $n=$ number of subjects. $2 . O R=$ Odds Ratio; $95 \% C I=95 \%$ confidence interval; $p$-value $=$ statistical significance; $3 .{ }^{a}$ statistically significant $p$-value; ${ }^{\mathrm{b}} p$-value considered borderline. $4{ }^{c}$ in the results section, $\mathrm{OR}$ is presented as 1.7 , as a conversion function by formula 1/OR for standardization. 5 . The "gender" line also had the ORs and CIs converted by the same formula.

\section{Discussion}

This study aimed to investigate how sociodemographic (gender and age) and psychological (body image dissatisfaction and self-esteem) variables are related to depressive and anxiety symptoms in adolescents. Initially, regarding the occurrence of CMD, the symptomatology rates 
Do self-esteem and gender help explain depressive and/or anxiety symptoms / Silva et al.

for isolated disorders were considered relatively below average, since $8.6 \%$ of adolescents had anxiety symptoms and just $2.6 \%$ exhibited only depressive symptoms. In Sergipe State, the prevalence of anxiety disorders between 10-19 years was approximately $11.2 \%$, similar to what is seen nationally. About depressive disorders, Sergipe had a prevalence of $5.1 \%$ among the above-mentioned age group, while the rates in Brazil for the same public were 5.2\% (IHME, 2017).

Although psychiatric disorders are heterogeneous, the similarity between some symptoms is discussed, which eventually makes it possible to establish different diagnoses in the same patient, such as comorbidities (Bochsloo et al., 2015). We can highlight the high comorbidity rate between anxiety and depressive symptoms observed in the present sample, covering approximately $70 \%$ of respondents. Comorbidity between depressive and anxiety disorders in adolescence is a common occurrence phenomenon that has been studied over time. According to one review, about $15.9 \%$ to $61.9 \%$ of children have been identified with comorbid symptoms for both disorders (Brady \& Kendall, 1992). Twenty years after this initial study, a new review was conducted, presenting several models and evidence regarding the involvement of dual symptomatology in children and adolescents (Cummings, Caporino, $\&$ Kendall, 2014). New studies cited by this review highlights that the comorbidity between anxiety and depression may vary due to existing anxiety disorder, which underlies the importance of examining developmental changes and specific anxiety disorders.

The prevalence of CMD in girls has been higher in several contexts. In this study, being female increased two times the chances of belonging to the group with anxiety symptoms, compared to not having any disorder, as it corroborates the literature regarding the higher involvement of anxiety disorders in girls (APA, 2014; Grolli, Wagner, \& Dalbosco, 2017; Lopes et al., 2016; Rentz-Fernandes et al., 2017). Considering that both depressive disorders and anxiety disorders have been common in adolescents, as well as the comorbidity between them (Avenevoli et al., 2015; Cummings et al., 2014), the need to identify CMD early and their main risk and protective factors is emphasized in 
order to reduce vulnerability to comorbidities and provide the basis for interventions aimed at this public (Lopes et al., 2016).

The self-esteem median of this survey can be considered moderate (27 points). From national data, which self-esteem measurement was divided only into two strata (low and high), 55.1\% of adolescents showed more than 28 points in the RSES, indicating high rates of selfesteem (Smouter, Coutinho, \& Mascarenhas, 2019). However, it is noteworthy that the diminishing of self-esteem was the factor that best explained the presence of anxiety and depressive symptoms separately, as well as positive symptoms for both disorders in this study.

The grade levels exhibited borderline values for the presence of anxiety symptoms and both disorders. However, given their importance for the age group investigated, it was considered pertinent to discuss such findings. We have seen that attending the third year of high school increased the chances of having anxiety symptoms by almost two times compared to having no disorder. It is understood that this framework may be associated with the college entrance exam or ENEM [Exame Nacional do Ensino Médio/National Exam of High School], as well as the difficulty of making decisions regarding the future (Andrade, Souza, \& Castro, 2016; Grolli et al., 2017). In addition, being in the first year increased the chance by $50 \%$ to belong to the group with both disorders compared to having no symptoms. It is believed that this fact may be associated with psychological suffering caused by the transition from elementary school to high school (Aguiar \& Conceição, 2009).

In sum, being female and having low or moderate self-esteem were the variables that best explained the presence of anxiety symptoms. As for depressive symptoms, having low self-esteem was the factor that best explained the existence of this disorder. Reduced self-esteem satisfactorily explained the presence of symptoms for both disorders. The grade level —a non-metric equivalent of age - exhibited borderline significance when related to the presence of anxiety symptoms and to both disorders. 
As limitations of the present investigation, it is noteworthy that the use of HADS has been debated in the literature due to its adequacy to accurately track anxiety and depressive symptoms (Maters, Sanderman, Kim, \& Coyne, 2013). As seen in a review of the scale (Cosco, Doyle, Ward, \& McGee, 2012), it is suggested that its result be interpreted as an assessment of psychological suffering (distress), which would integrate symptoms of anxiety and depression in an integrated manner. In this sense, attention is suggested when interpreting HADS scores and caution in interpreting the high comorbidity rate detected here. Another limitation concerns the non-statistical significance of the dissatisfaction with the body image variable, which may be associated with a possible difficulty of respondents to understand the form of response for the scale used. Although it is not possible to attest to such difficulty for the sample as a whole, it is believed that the use of other screening measures for this phenomenon will be interesting in future research with adolescents.

Regarding strengths, the quality of the sample stands out due to its relatively large size. Additionally, the importance of mental health symptomatology screening studies is reiterated, especially with the adolescent public. Finally, mapping risk or protective factors for the development of CMD in this life phase favors the proposition of interventions focused on modifying health behaviors, both at this stage and for the next stages throughout life.

\section{References}

Aguiar, F. H. R., \& Conceição, M. I. G. (2009). Expectativas de futuro e escolha vocacional em estudantes na transição para o ensino médio [Expectations about the future and vocational choice of students moving to high school]. Revista Brasileira de Orientação Profissional, 10(2), 105-115. Retrieved from https://www. redalyc.org/pdf/2030/203014923011.pdf 
American Psychiatric Association [APA]. (2014). Manual diagnóstico e estatístico de transtornos mentais: DSM-5 (5a ed., Diagnostic and statistical manual of mental disorders, Trad.). Porto Alegre: Artmed.

Andrade, T. M., Souza, V. N., \& Castro, N. R. (2016). Nível de ansiedade e estresse em adolescentes concluintes do ensino médio [Anxiety level and stress in adolescents concluding high school]. Revista Cientifica Univiçosa, 8, 595-600. Retrieved from https:// academico.univicosa.com.br/revista/index.php/RevistaSimpac/ article/view/706

Avanci, J. Q., Assis, S. G., Santos, N. C., \& Oliveira, R. V. C. (2007). Adaptação transcultural de escala de auto-estima para adolescentes [Cross-cultural adaptation of self-esteem scale for adolescents]. Psicologia: Reflexão e Crítica, 20(3), 397-405. https://doi.org/10.1590/S0102-79722007000300007

Avenevoli, S., Swendsen, J., He, J.-P., Burstein, M., \& Merikangas, K. R. (2015). Major depression in the National Comorbidity SurveyAdolescent supplement: Prevalence, correlates, and treatment. Journal of the American Academy of Child \& Adolescent Psychiatry, 54(1), 37-44. https://doi.org/10.1016/j.jaac.2014.10.010

Boschloo, L., Borkulo, C. D., Rhemtulla, M., Keyes, K. M., Borsboom, D., \& Schoevers, R. A. (2015) The network structure of symptoms of the diagnostic and statistical manual of mental disorders. PLoS ONE, 10(9), e0137621. https://doi.org/10.1371/journal. pone. 0137621

Botega, N. J., Bio, M. R., Zomignani, M. A., Garcia Jr, C., \& Pereira, W. A. B. (1995). Transtornos do humor em enfermaria de clínica médica e validação de escala de medida (HAD) de ansiedade e depressão [Mood disorders among medical in-patients: A validation study of the hospital anxiety and depression scale (HAD)]. Revista de Saúde Pública, 29(5), 355-363. https://doi. org/10.1590/S0034-89101995000500004

Brady, E. U., \& Kendall, P. C. (1992). Comorbidity of anxiety and depression in children and adolescents. Psychological Bulletin, 


\section{1(2), 244-255. http://doi.org/10.1037/0033-2909.111.2.2 44}

Chan, C.Y., Koh, Y. W., \& Lee, A. (2014) Hospital Anxiety and Depression Scale for use among adolescents. In A. C. Michalos (Eds.), Encyclopedia of quality of life and well-being research (pp. 2933-2938). Springer.

Cosco, T. D., Doyle, F., Ward, M., \& McGee, H. (2012). Latent structure of the Hospital Anxiety and Depression Scale: A 10-year systematic review. Journal of Psychosomatic Research, 72(3), 180-184. http://doi.org/10.1016/j.jpsychores.2011.06.008

Cummings, C. M., Caporino, N. E., \& Kendall, P. C. (2014). Comorbidity of anxiety and depression in children and adolescents: 20 years after. Psychological Bulletin, 140(3), 816-845. https://doi. org/10.1037/a0034733

Das, J. K., Salam, R. A., Lassi, Z. S., Khan, M. N., Mahmood, W., Patel, V., \& Bhutta, Z. A. (2016). Interventions for adolescent mental health: An overview of systematic reviews. Journal of Adolescent Health, 59, S49-S60. https://doi.org/10.1016/j. jadohealth.2016.06.020

Del Ciampo, L. A., \& Del Ciampo, I. R. L. (2010). Adolescência e imagem corporal [Adolescence and body image]. Adolescência \& Saúde, 7(4), 55-59. Retrieved from http://www.adolescenciaesaude.com/detalhe_artigo.asp?id=246

Faro, A., \& Kluge, A. B. S. (2018). Psicologia da saúde do adolescente e os mecanismos psicológicos de adaptação [Adolescent health psychology and the psychological mechanisms of adaptation]. In J. P. Silva, A. Faro, \& E. Cerqueira-Santos (Orgs.), Psicologia e adolescência: Gênero, violência e saúde [Psychology and adolescence; Gender, violence and health] (pp. 204-229). CRV.

Field, A. (2009). Descobrindo a estatística usando o SPSS (2a ed., Discovering statistics with SPSS 2nd ed., Trad.). Artmed.

Garson, D. (2012). Logistic regression: Binary and multinomial. Statistical Associates Publishers. 
Gonçalves, J. C. S., \& Sampaio, A. G. P. (2016). Estudo dos fatores determinantes de transtornos mentais em adolescentes: Revisão sistemática [Study of factors in mental health determinants disorders teens: Systematic review]. Revista Interfaces - Saúde, Humanas e Tecnologia, 3(9), 55-59. Retrieved from http://interfaces.leaosampaio.edu.br/index.php/revista-interfaces/article/ view/209

Gonçalves, V. O., \& Martínez, J. P. (2014). Imagem corporal de adolescentes: um estudo sobre as relaçóes de gênero e influência da mídia [Body image of adolescents: A study on gender relations and influence of the mass media]. Comunicação \& Informação, 17(2), 139-154. https://doi.org/10.5216/31792

Grogan, S. (2008). Body image: Understanding body dissatisfaction in men, women and children. Routledge.

Grolli, V., Wagner, M. F., \& Dalbosco, S. N. P. (2017). Sintomas depressivos e de ansiedade em adolescentes do ensino médio [Depressive and anxiety symptoms in high school adolescents]. Revista de Psicologia da IMED, 9(1), 87-103. https://doi. org/10.18256/2175-5027.2017.v9i1.2123

Hutz, C. S., \& Zanon, C. (2011). Revisão da adaptaçáo, validação e normatização da escala de autoestima de Rosenberg [Revision of the adaptation, validation, and normatization of the Rosenberg self-esteem scale]. Avaliação Psicológica, 10, 41-49. Retrieved from http://pepsic.bvsalud.org/scielo.php?script=sci_arttext\&p $\mathrm{id}=$ S1677-04712011000100005

Instituto Brasileiro de Geografia e Estatística (2017). Brasil em sintese: Sergipe [Brazil in summary: State of Sergipe]. Retrieved from http://cidades.ibge.gov.br/brasil/se/panorama

Institute for Health Metrics and Evaluation [IHME] (2017). Global Burden of Disease Results. Retrieved from http://ghdx.healthdata. org/gbd-results-tool?params=gbd-api-2017-permalink/2286b3f cc7d4b1f9c167aac682598726

Lopes, C. S., Abreu, G. A., Santos, D. F., Menezes, P. R., Carvalho, K. M. B., Cunha, C. F., ... Szklo, M. (2016). ERICA: Prevalência 
Do self-esteem and gender help explain depressive and/or anxiety symptoms / Silva et al.

de transtornos mentais comuns em adolescentes brasileiros [ERICA: Prevalence of common mental disorders in Brazilian adolescents]. Revista de Saúde Pública, 50(supl 1), 14s. https:// doi.org/10.1590/S01518-8787.2016050006690

Maters, G. A., Sanderman, R., Kim, A. Y., \& Coyne, J. C. (2013). Problems in cross-cultural use of the Hospital Anxiety and Depression Scale: "No butterflies in the desert". PloS One, 8(8), e70975. https://doi.org/10.1371/journal.pone.0070975

Miranda, V. P. N., Conti, M. A., Carvalho, P. H. B., Bastos, R. R., \& Ferreira, M. E. C. (2014). Imagem corporal em diferentes períodos da adolescência [Body image in different periods of adolescence]. Revista Paulista de Pediatria, 32, 63-69. https:// doi.org/10.1590/S0103-05822014000100011

Pan America Health Organization [PAHO]. (2018). The burden of mental disorders in the region of the Americas. Washington, D.C.: PAHO. Retrieved from http://iris.paho.org/xmlui/ bitstream/handle/123456789/49578/9789275120286_eng. pdf? sequence $=10 \&$ is Allowed $=y$

Rentz-Fernandes, A. R., Silveira-Viana, M., Liz, C. M., \& Andrade, A. (2017). Autoestima, imagem corporal e depressão de adolescentes em diferentes estados nutricionais [Self-esteem, body image and depression in adolescents with different nutritional conditions]. Revista Salud Pública, 19, 66-72. https://doi. org/10.15446/rsap.v19n1.47697

Resende, C., Santos, E., Santos, P., \& Ferrão, A. (2013). Depressão nos adolescentes - mito ou realidade? [Depression in adolescents - myth or reality?]. Nascer e Crescer - Revista de Pediatria do Centro Hospitalar do Porto, 22(3), 145-150. Retrieved from http://www.scielo.mec.pt/scielo.php?script=sci_arttext \&p $\mathrm{id}=$ S0872-07542013000300003

Rosenberg, M. (1965). Society and the adolescent self-image. Princeton University Press.

Sena, R. M. C., \& Maia, E. M. C. (2017). A utilização do constructo da autoestima nas pesquisas em saúde no Brasil: Contribuiçóes 
conceituais à prática clínica [The use of the construct of selfesteem in health research in Brazil: Conceptual contributions towards clinical practice]. Humanidades Médicas, 17(2), 383-395. Retrieved from http://www.humanidadesmedicas.sld. cu/index.php/hm/article/view/1043

Scagliusi, F. B., Alvarenga, M., Polacow, V. O., Cordás, T. A., Queiroz, G. K. O. Q., Coelho, D., ... Lancha Jr, A. H. (2006). Concurrent and discriminant validity of the Stunkard's Figure Rating Scale adapted into Portuguese. Appetite, 47, 77-82. https://doi. org/10.1016/j.appet.2006.02.010

Silva, A. M. B., Machado, W. L., Bellodi, A. C., Cunha, K. S., \& Enumo, S. R. F. (2018). Jovens insatisfeitos com a imagem corporal: Estresse, autoestima e problemas alimentares [Young people dissatisfied with body image: Stress, self-esteem and eating problems]. Psico-USF, 23(3), 483-495. https://doi.org/1 0.1590/1413-82712018230308

Smouter, L., Coutinho, S. S., \& Mascarenhas, L. P. G. (2019). Associação en tre nível de atividade física e autoconceito de autoestima de adolescentes [Association between physical activity levels and adolescents' self-perception of self-esteem]. Ciência \& Saúde Coletiva, 24(2), 455-464. Retrieved from http://www.scielo.br/ pdf/csc/v24n2/1678-4561-csc-24-02-0455.pdf

Stunkard, A., Sorensen, T., \& Schlusinger, F. (1983). Use of danish adoption register for the study of obesity and thinness. In $S$. Kety, L. P. Rowland, R. L. Sidman, \& S. W. Matthysse (Eds.), The genetics of neurological and psychiatric disorders (pp. 115-20). Raven.

Tuijl, L. A., Jong, P. J., Sportel, B. E., Hullu, E., \& Nauta, M. H. (2014). Implicit and explicit self-esteem and their reciprocal relationship with symptoms of depression and social anxiety: A longitudinal study in adolescents. Journal of Behavior Therapy and Experimental Psychiatry, 45, 113-121. https://doi. org/10.1016/j.jbtep.2013.09.007 
World Health Organization [WHO]. (2017). Depression and other common mental disorders: Global health estimates. Geneva: WHO Document Production Services. Retrieved from http://apps. who.int/iris/bitstream/handle/10665/254610/WHO-MSDMER-2017.2-eng.pdf

World Health Organization [WHO]. (2018). Adolescent mental health. Retrieved from http://www.who.int/news-room/ fact-sheets/detail/adolescent-mental-health

Zigmond, A. S., \& Snaith, R. P. (1983). The Hospital Anxiety and Depression Scale. Acta Psychiatrica Scandinavica, 67, 361-370. https://doi.org/10.1111/j.1600-0447.1983.tb0971

Recibido: 2020-04-20

Revisado: 2021-11-11

Aceptado: 2021-12-02 